\title{
Chronic Zinc Deficiency Alters Chick Gut Microbiota Composition and Function
}

\author{
Spenser Reed ${ }^{1,2,3}$, Hadar Neuman ${ }^{4}$, Sharon Moscovich ${ }^{4}$, Raymond P. Glahn ${ }^{1}$, Omry Koren ${ }^{4}$ \\ and Elad Tako ${ }^{1, *}$
}

Received: 11 September 2015; Accepted: 12 November 2015; Published: 27 November 2015

1 USDA-ARS Robert Holley Center for Agriculture and Health, Ithaca, NY 14853, USA;

smr2@cornell.edu (S.R.); rpg3@cornell.edu (R.P.G.)

2 Division of Nutritional Sciences, Cornell University, Ithaca, NY 14853, USA

3 College of Medicine, the University of Arizona, Tucson, AZ 85724, USA

4 Faculty of Medicine, Bar-Ilan University, 8 Henrietta Szold St, Safed 1311502, Israel;

hadarneuman@gmail.com (H.N.); sharonmosc@gmail.com (S.M.); Omry.Koren@biu.ac.il (O.K.)

* Correspondence: et79@cornell.edu; Tel.: +1-607-255-5434; Fax: +1-607-255-1132

\begin{abstract}
Zinc (Zn) deficiency is a prevalent micronutrient insufficiency. Although the gut is a vital organ for Zn utilization, and Zn deficiency is associated with impaired intestinal permeability and a global decrease in gastrointestinal health, alterations in the gut microbial ecology of the host under conditions of Zn deficiency have yet to be studied. Using the broiler chicken (Gallus gallus) model, the aim of this study was to characterize distinct cecal microbiota shifts induced by chronic dietary $\mathrm{Zn}$ depletion. We demonstrate that $\mathrm{Zn}$ deficiency induces significant taxonomic alterations and decreases overall species richness and diversity, establishing a microbial profile resembling that of various other pathological states. Through metagenomic analysis, we show that predicted Kyoto Encyclopedia of Genes and Genomes (KEGG) pathways responsible for macro- and micronutrient uptake are significantly depleted under Zn deficiency; along with concomitant decreases in beneficial short chain fatty acids, such depletions may further preclude optimal host $\mathrm{Zn}$ availability. We also identify several candidate microbes that may play a significant role in modulating the bioavailability and utilization of dietary $\mathrm{Zn}$ during prolonged deficiency. Our results are the first to characterize a unique and dysbiotic cecal microbiota during $\mathrm{Zn}$ deficiency, and provide evidence for such microbial perturbations as potential effectors of the $\mathrm{Zn}$ deficient phenotype.
\end{abstract}

Keywords: zinc deficiency; microbiota; dysbiosis; cecal microbiome; zinc biomarker

\section{Introduction}

$\mathrm{Zn}$, an essential nutrient for nearly all organisms, is most notably involved as a metal cofactor in hundreds of proteins within the human body [1,2]. In healthy adults, $\mathrm{Zn}$ is present in the amount of $2-3 \mathrm{~g}$ and is second only to iron ( $\mathrm{Fe})$ as the most abundant micronutrient [3,4]. Even mild deficiencies of this mineral can profoundly impact growth and development, as well as impede immune differentiation and maturation [5,6]. The spectrum of chronic $\mathrm{Zn}$ deficiencies has been recently estimated to affect around $17 \%$ of the population [7], with insufficient dietary Zn intake and/or poor bioavailability from food central to this condition $[8,9]$. Despite the high prevalence of $\mathrm{Zn}$ deficiency, accurate clinical biomarkers of $\mathrm{Zn}$ status are lacking $[10,11]$. To address this, a major initiative set forth by the World Health Organization, the International Zinc Nutrition Consultative Group, and others has been to promote the development of reliable $\mathrm{Zn}$ biomarkers. Although serum $\mathrm{Zn}$ is currently the most widely used biomarker of $\mathrm{Zn}$ status, inherent problems with its measurement and interpretation can significantly impact sensitivity and specificity for dietary Zn [11]. To that end, our group recently published evidence in this journal for a new biological indicator of $\mathrm{Zn}$ 
status, the linoleic acid: dihomo- $\gamma$-linolenic acid (LA:DGLA) ratio, which exploits the $\mathrm{Zn}$-dependent rate-limiting step of erythrocyte fatty acid desaturation [12]. Yet, since no single reliable biomarker of $\mathrm{Zn}$ status currently exists, establishing a panel of biochemical indices, as is the case with functional Fe deficiency [13,14], may be necessary.

Understanding the influence of the gastrointestinal microbiota on physiology may represent a novel area to also understand the effects of $\mathrm{Zn}$ deficiency on the host. Little is known about how dietary $\mathrm{Zn}$ contributes to the microbiota, and even less is known regarding the effects of chronic $\mathrm{Zn}$ deficiency on the gut microbial composition. Early work by Smith et al. [15] elucidated a role of the host microbiota in $\mathrm{Zn}$ homeostasis, whereby conventionally-raised (CR, Conventionally-raised) mice required nearly twice as much dietary $\mathrm{Zn}$ than did their germ-free (GF) counterparts. In the same study, an in vitro assay using radiolabeled ${ }^{65} \mathrm{Zn}$ identified a Streptococcus sp. and Staphylococcus epidermidis able to concentrate $\mathrm{Zn}$ from the medium. In this study, GF animals also had a reduced cecal $\mathrm{Zn}$ concentration relative to their $\mathrm{CR}$ counterparts.

Recently, it was shown [16] that Zn competition exists in C. jejuni and other bacterial species in the host microbiota of CR versus GF broiler chickens (Gallus gallus). Under conditions of $\mathrm{Zn}$ deficiency, this might lead to the preferential growth of bacteria able to survive at low-Zn levels. Further, many recent studies have shown that prophylactic doses of $\mathrm{Zn}$ (as $\mathrm{Zn}$ oxide, $\mathrm{ZnO}$ ) in various animal models increased the presence of Gram-negative facultative anaerobic bacterial groups, the colonic concentration of short chain fatty acids (SCFAs), as well as overall species richness and diversity [17-19]. Likewise, others have found a gut microbiota enriched in members of the phylum Firmicutes, specifically Lactobacillus, following $\mathrm{ZnO}$ administration [20]. Therapeutic levels of dietary $\mathrm{Zn}$ have been shown to alter the overall gut microbial composition of piglets leading to favorable changes in its metabolic activity [21,22]. Protective effects of $\mathrm{Zn}$ supplementation include modulating intestinal permeability (via proliferation of the absorptive mucosa) [23,24], reducing villous apoptosis [25], influencing the Th1 immune response [26], and reducing pathogenic infections and subsequent diarrheal episodes [23].

Although the gut environment is central to $\mathrm{Zn}$ homeostasis, and is affected by suboptimal $\mathrm{Zn}$ status, we know little about the effects of chronic dietary $\mathrm{Zn}$ deficiency on the composition and function of the gut microbiome. Therefore, the present study examined how a 4 weeks period of $\mathrm{Zn}$ deficiency affected the composition and genetic potential of the cecal microbiota in broiler chickens fed a moderately $\mathrm{Zn}$ deficient diet. A panel of $\mathrm{Zn}$ status biomarkers was measured weekly, and gene expression of a variety of $\mathrm{Zn}$-dependent proteins was quantified from relevant tissues at study conclusion. Cecal contents were collected for SCFA quantification and for analyzing compositional and functional alterations in the microbiota.

\section{Experimental Section}

\subsection{Animals, Diets, and Experimental Design}

Upon hatching, chicks were randomly allocated into two treatment groups on the basis of body weight and gender (aimed to ensure equal distribution between groups, $n=12$ ): $1 . \mathrm{Zn}(+): 42 \mu \mathrm{g} / \mathrm{g}$ zinc; $2 . \mathrm{Zn}(-): 2.5 \mu \mathrm{g} / \mathrm{g}$ zinc. Experimental diets are shown in Supplemental Table 1. At study conclusion, birds were euthanized. The digestive tracts (colon and small intestine) and liver were quickly removed and stored as was previously described [12]. All animal protocols were approved by the Cornell University Institutional Animal Care and Use committee.

\subsection{Determination of Zn Status}

Zn status parameters were determined as described in the Supplemental Materials and Methods. 


\subsection{Isolation of Total RNA}

Total RNA was extracted from $30 \mathrm{mg}$ of duodenal (proximal duodenum, $n=9$ ) and liver tissues $(n=9)$ as described in the Supplemental Materials and Methods. Supplemental Table 2 shows the measured genes.

\subsection{Cecal SCFA Analysis}

SCFA concentration was determined as described in the Supplemental Materials and Methods.

\subsection{S rRNA PCR (Polymerase Chain Reaction) Amplification and Sequencing}

Microbial genomic DNA was extracted from cecal samples as described in the Supplemental Materials and Methods.

\section{6. $16 S$ rRNA Gene Sequence Analysis}

$16 \mathrm{~S}$ rRNA analysis was performed as described in the Supplemental Materials and Methods.

\subsection{Statistical Analysis}

Biomarkers of Zn deficiency (Figure 1) are presented as means \pm SEM. ANOVA was performed to identify significant differences between the means of the experimental groups of birds, unless otherwise stated. Spearman's correlation was used to assess significant associations between bacterial groups and biomarkers of $\mathrm{Zn}$ status. False discovery rate adjusted $p$-values were calculated for comparisons of taxa. $p<0.05$ was considered significant. All statistical tests were two-tailed and were carried out using SAS version 9.3 (SAS Institute, Cary, NC, USA).
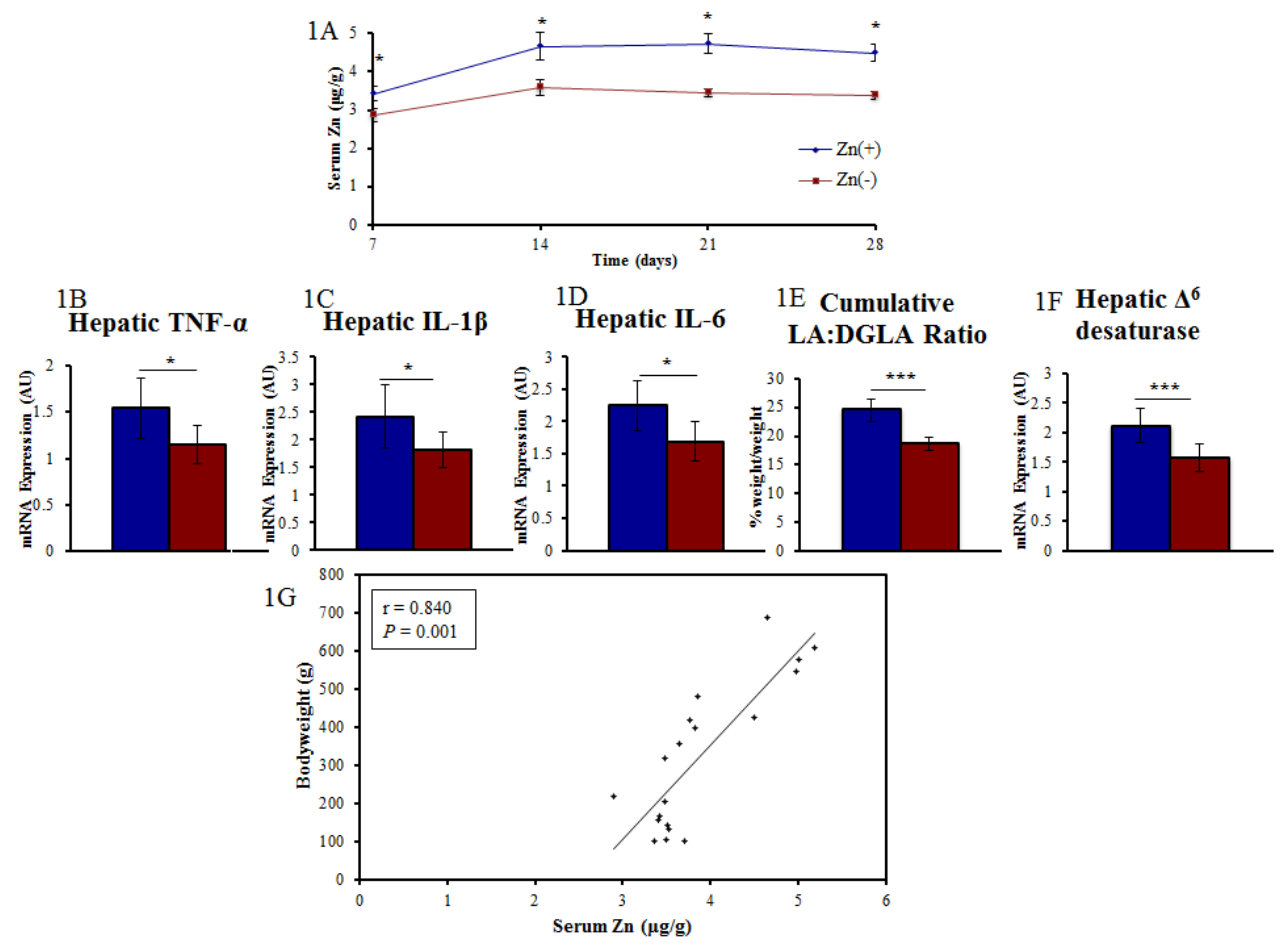

Figure 1. Measured Zn status parameters. (A) Day 7, 14, 21, and 28 serum Zn levels were significantly different between treatment groups $\left(n=12,{ }^{*} p<0.05\right.$, ANOVA); (B-D) mRNA gene expression of hepatic tissue excised at the conclusion of study ( $n=12$, day $28,{ }^{*} p<0.05$, ANOVA); (E,F) Additional Zn biomarkers utilizing erythrocyte fatty acid composition ( $\left.{ }^{* * *} p<0.001, n=12\right)$; (G) Linear correlation between bodyweight and serum Zn on day 28 . 


\section{Results}

\subsection{A Panel of Sensitive Biomarkers Defines a Marked Difference in Zn Status between Treatment Groups}

Results of the $\mathrm{Zn}$ status biomarkers used in this study were adapted from our recent publication [12]. Due to the lack of a singular marker of Zn intake and deficiency [27,28], we opted to use an array of biological indicators of Zn status-including growth (bodyweight), immunological (hepatic mRNA expression of cytokines), and physiological (tissue $\mathrm{Zn}$, serum $\mathrm{Zn}$, and the erythrocyte LA:DGLA ratio) parameters- to confirm $\mathrm{Zn}$ deficiency in the $\mathrm{Zn}(-)$ treatment group. As expected, these indicators (Figure 1A-F) were significantly different between animals receiving a $\mathrm{Zn}$ adequate semi purified diet ([29]; $\mathrm{Zn}(+), 42 \mu \mathrm{g} / \mathrm{g} \mathrm{Zn})$ versus those receiving a $\mathrm{Zn}$ deficient diet $(\mathrm{Zn}(-)$, $2.5 \mu \mathrm{g} / \mathrm{g} \mathrm{Zn).} \mathrm{Relative} \mathrm{hepatic} \mathrm{mRNA} \mathrm{gene} \mathrm{expression} \mathrm{of} \mathrm{the} \mathrm{pro-inflammatory} \mathrm{cytokines} \mathrm{IL-1} \beta$, IL-6, and Th2 dominant TNF- $\alpha$ were significantly reduced in the Zn deficient group, supporting a central role for dietary $\mathrm{Zn}$ in the production of cytokines and immunoregulation [30-32]. The chronic feeding of a $\mathrm{Zn}$ deprived diet resulted in a measureable $\mathrm{Zn}$ deficiency in the $\mathrm{Zn}(-)$ animals relative to their $\mathrm{Zn}(+)$ counterparts.

\subsection{Gut Microbial Diversity of Zn Deficient Animals Resembles Physiologically Diseased Microbiomes}

Cecal samples from the $\mathrm{Zn}(+)$ and $\mathrm{Zn}(-)$ treatment groups were harvested and used for bacterial DNA extraction and sequencing of the V4 hypervariable region in the 16S rRNA gene. The cecum represents the primary site of bacterial fermentation in Gallus gallus, with its resident microbiota highly diverse and abundant [33]. As in humans, Firmicutes are by far the dominant bacterial phylum in the Gallus gallus cecum, accounting for $70 \%-90 \%$ of all sequences [34,35].

The diversity of the cecal microbiota in the $\mathrm{Zn}(+)$ and $\mathrm{Zn}(-)$ groups was assessed through measures of $\alpha$-diversity, $\beta$-diversity, and overall species richness (Figure 2). The Chao1 index and observed species richness were used to assess $\alpha$-diversity. For both measures, the $\mathrm{Zn}$ deficient group had significantly lower phylogenetic diversity, indicating a less diverse cecal microbial composition (Figure 2A,B). We utilized weighted UniFrac distances as a measure of $\beta$-diversity to assess the effect of chronic Zn deficiency on between-individual variation in bacterial community composition. Principal coordinate analysis demonstrated a significant expansion of $\beta$-diversity in the $\mathrm{Zn}$ deficient group (Figure 2C). Interestingly, the same features of lower $\alpha$-diversity and richness together with higher $\beta$-diversity compared to the control as seen in Zn deficiency are also found in GI microbiota observed during a deficiency of the trace mineral selenium [36], as well as in various pathological states such as Crohn's disease [37], inflammatory bowel disease [38], opportunistic infections [39], diabetes [40], obesity [41] and others [42]. 


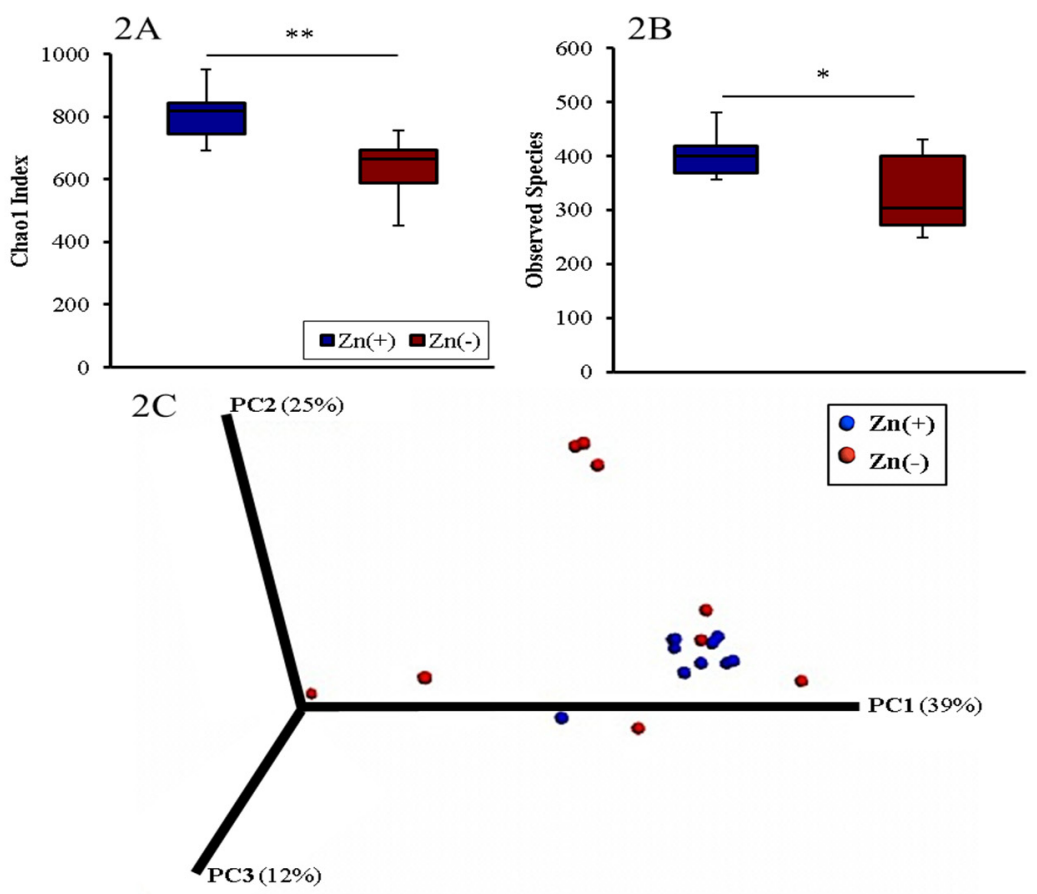

Figure 2. Microbial diversity of the cecal microbiome. (A) Measures of $\alpha$-diversity using the Chao1 Index [39]; and (B) total number of observed species ${ }^{*} p<0.05,{ }^{* *} p<0.01$, ANOVA, $n=10$ in $\mathrm{Zn}(+), n=9$ in $\mathrm{Zn}(-)$; (C) Measure of $\beta$-diversity using weighted UniFrac distances separated by the first three principal components (PC). Each dot represents one animal, and the colors represent the different treatment groups.

\subsection{Chronic Zn Deficiency Reshapes the Gut Microbiome}

We performed a taxon-based analysis of the cecal microbiota (Figure 3). 16S rRNA gene sequencing revealed that $98 \%-99 \%$ of all bacterial sequences in both the $\mathrm{Zn}(+)$ and $\mathrm{Zn}(-)$ groups belonged to four major divisions: Firmicutes, Proteobacteria, Bacteroidetes, and Actinobacteria. Bacterial community composition was altered in the $\mathrm{Zn}$ deficient group, where significantly greater abundance of Proteobacteria and significantly lower abundance of Firmicutes (Figure 3A) was observed. In the $\mathrm{Zn}(-)$ group, the abundance of Bacteroidetes was increased whereas Actinobacteria was diminished, albeit not significantly. As such, the ratio of Firmicutes: Proteobacteria, was significantly lower in the Zn deficient group (Figure 3B). Further, the abundance of Proteobacteria inversely correlated with bodyweight (Figure 3C). Because of the central importance of $\mathrm{Zn}$ in growth and development, bodyweight is often the first anthropometric measurement to respond to $\mathrm{Zn}$ depletion and to quantify risk of complications related to $\mathrm{Zn}$ deficiency [43]. It has been a consistently reliable indicator of low $\mathrm{Zn}$ intake and $\mathrm{Zn}$ status in multiple cohorts and experimental models, and has been used by numerous others to quantify suboptimal dietary Zn deficiency [44,45]. Likewise in this study, final bodyweight strongly correlated with final serum $\mathrm{Zn}(\rho=0.84, p=0.0012$, Figure $1 \mathrm{G})$. At the family-level, Peptostreptococcaceae and unclassified Clostridiales were significantly lower, whereas Enterococcaceae and Enterobacteriaceae were significantly enriched, in the $\mathrm{Zn}$ deficient group. At the genus-level, we observed that Zn deficient animals had significantly higher relative abundance of Enterococcus, unclassified Enterobacteriaceae, and unclassified Ruminococcaceae, and significantly lower relative abundance of unclassified Clostridiales and unclassified Peptostreptococcaceae compared with their Zn replete counterparts (Figure 3D). 

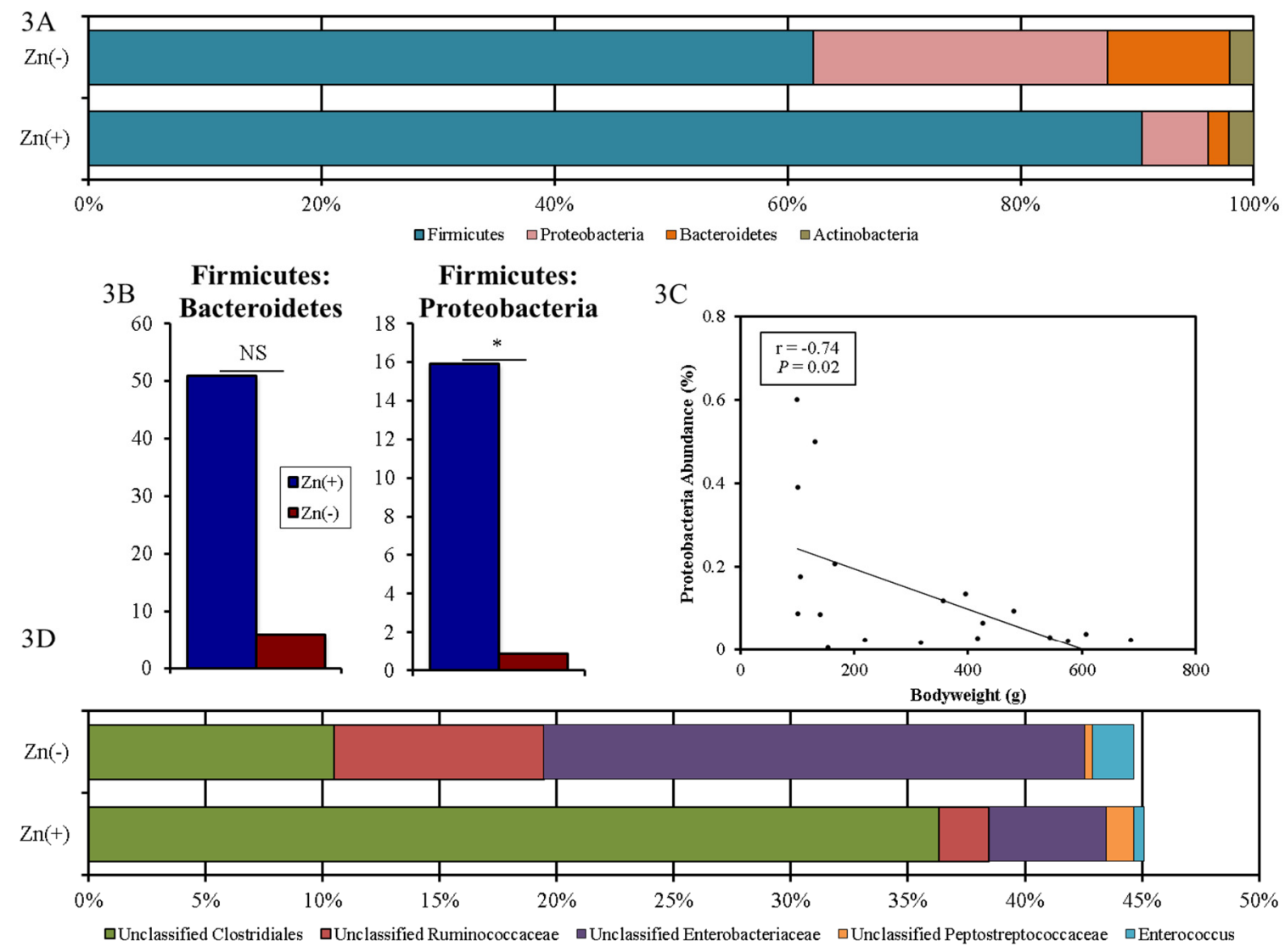

Figure 3. Phylum- and genera-level cecal microbiota shifts due to dietary Zn depletion. (A) Phylum-level changes between the $\mathrm{Zn}(+)$ and $\mathrm{Zn}(-)$ groups as measured at the end of the study (day 28). Only those phyla with abundance $>1 \%$ are shown; (B) Increased Firmicutes to Bacteroidetes and Proteobacteria ratios in the $\mathrm{Zn}(+)$ group $\left({ }^{*} p<0.05, \mathrm{NS}=\right.$ not statistically significant); (C) Inverse correlation between Proteobacteria abundance and bodyweight; (D) Genus-level changes in the $\mathrm{Zn}(+)$ and $\mathrm{Zn}(-)$ group as measured at the end of the study (day 28). Only those genera significantly different between groups are shown.

We next investigated whether taxonomic shifts at the genus level were associated with host phenotype, as defined by bodyweight and serum $\mathrm{Zn}$ (as measured on day 28, Figure 4), two commonly utilized biomarkers of Zn deficiency. Among the $\mathrm{Zn}$ replete animals, a significant inverse correlation was obtained between average serum $\mathrm{Zn}$ levels and Eggerthella abundance. There was also a significant positive correlation between body weight and Rikenellaceae abundance in this group. In the $\mathrm{Zn}$ deficient group, a significant positive correlation was obtained between bodyweight and the abundance of Peptostreptococcaceae.

The ratio of certain bacterial groups may be predictive of shifts in the genetic capacity of the microbiome in certain physiological processes (e.g., the Firmicutes:Bacteroidetes ratio and caloric extraction from diet [46]. Studies have yet to characterize or relate taxonomic changes induced by dietary $\mathrm{Zn}$ deficiency to markers of the phenotype, yet such ratio analyses may further define a cecal microbiota signature of the deficiency. Our analysis revealed that several ratios of the significantly altered genera in the $\mathrm{Zn}(-)$ group were also significantly different during $\mathrm{Zn}$ deficiency. The ratios of the relative abundance of Unclassified Clostridiales:Enterococcus (UC:E), Unclassified Clostridiales:Ruminococcaceae (UC:R), Unclassified Clostridiales:Unclassified Enterobacteriaceae (UC:UE), and Peptostreptococcaceae:Enteroccocus (P:E) were significantly different between the $\mathrm{Zn}(+)$ and $\mathrm{Zn}(-)$ treatment groups (Figure 4B). Additionally, there was a significant, treatment-specific correlation 
between one of these ratios, Peptostreptococcaceae:Enterococcus, and bodyweight in the $\mathrm{Zn}$ deficient group (Figure 4C).
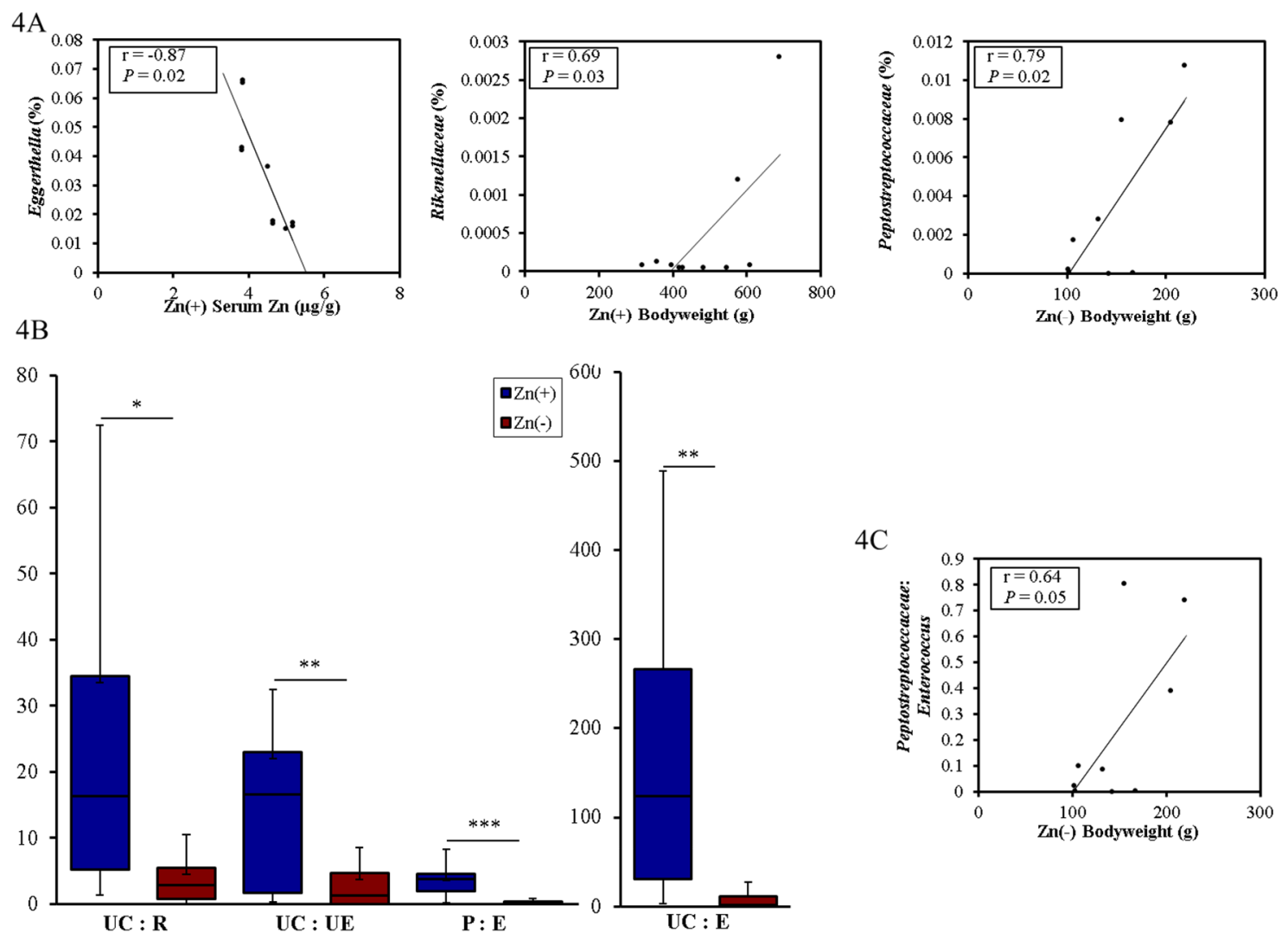

Figure 4. Genera-level correlations and ratios of cecal bacteria between the $\mathrm{Zn}(+)$ and $\mathrm{Zn}(-)$ groups. (A) Relative abundance of certain bacterial genera that significantly correlate with either treatment-specific serum $\mathrm{Zn}$ or bodyweight; (B) Ratios of bacterial genera that are significantly higher in the $\mathrm{Zn}(+)$ group $\left(^{*} p<0.05\right.$, ** $p<0.01$, *** $p<0.001$, ANOVA); (C) Peptostreptococcaceae:Enterococcus ratio positively correlates with bodyweight in the $\mathrm{Zn}$ deficiency group.

In light of these taxonomic alterations, we further analyzed community shifts to the species-level. We identified a strong positive correlation between Ruminococcus lactaris, Enterococcus sp., Clostridium lactatifermentans, and Clostridium clostridioforme and $\mathrm{Zn}$ adequacy, as well as between the latter three operational taxonomic units (OTUs) and final bodyweight and serum Zn measurements (Figure 5). The levels of two additional bacterial species, Clostridium indolis and an unclassified member of the Bacteroidales (Unclassified S24-7), were inversely correlated with final bodyweight and dietary Zn adequacy. Although not significant, it is interesting that the trend in correlation presented in Figure 5 (i.e., positive OTU correlation with Ruminococcus lactaris, Enterococcus sp., Clostridium lactatifermentans, and Clostridium clostridioforme and negative OTU correlation with Unclassified S24-7 and Clostridium indolis) does extend to the mRNA gene expression data. 


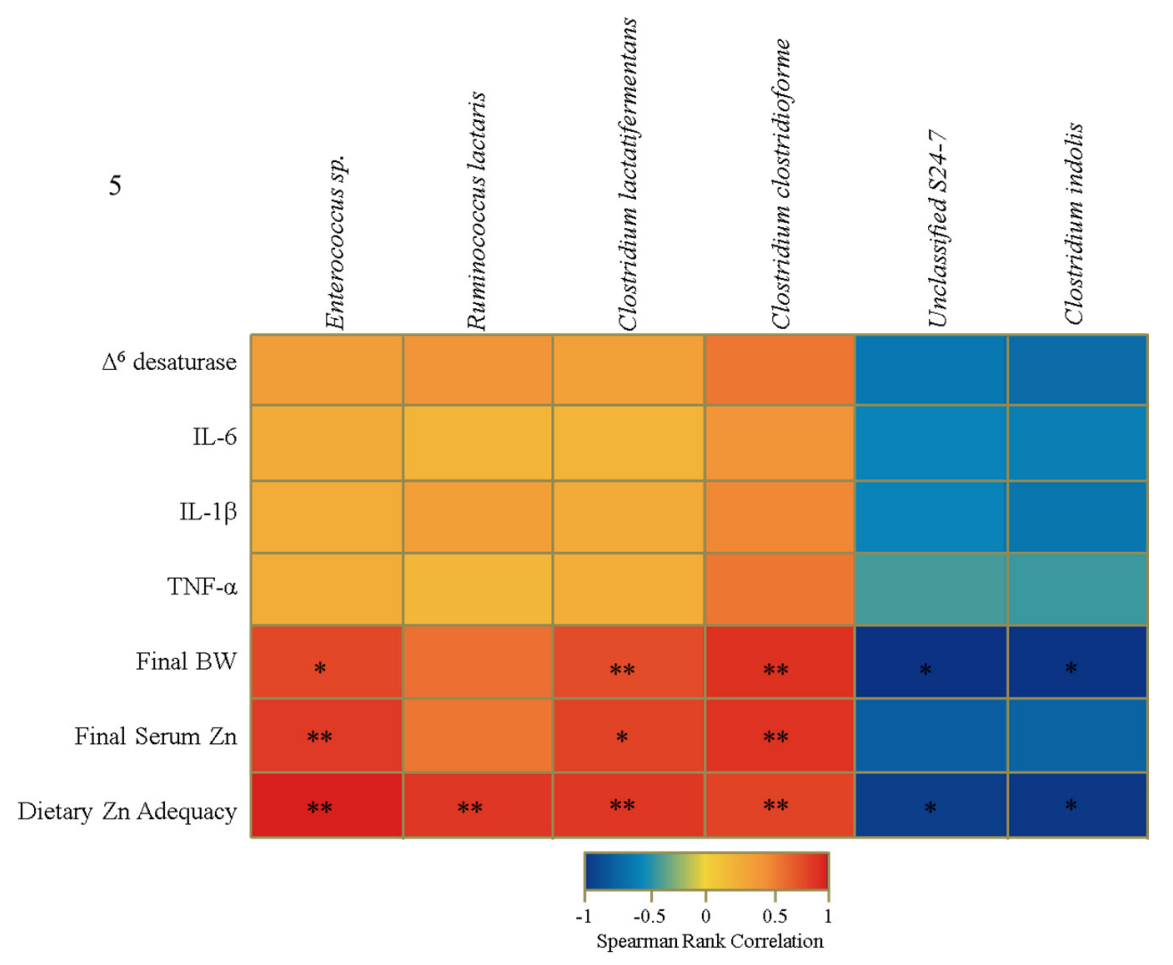

Figure 5. Heat map describing a set of Spearman correlations, independent of treatment group, between the relative abundance of different operational taxonomic units (OTUs) and select biological indicators of $\mathrm{Zn}$ status. The color indicator ranges from a perfect negative correlation $(-1$, blue $)$ to a perfect positive correlation $(1$, red $)\left({ }^{*} p<0.05,{ }^{* *} p<0.01\right.$, ANOVA).

\subsection{Functional Alterations in the Genetic Capacity of Cecal Microbiota under Zn Deficiency Conditions}

We next sought to understand whether the genetic capacity of the microbiota may influence host $\mathrm{Zn}$ status, since there were significant community shifts associated with physiological markers of Zn deficiency. The study of metagenomic alterations among various phenotypes (e.g., inflammatory bowel disease, obesity) and between healthy and diseased subjects has helped to elucidate how the functional shifts of the microbiota may affect the trajectory of the disease process [47]. However, the medical significance of alterations in the metabolic or functional capacity of the host microbiome under $\mathrm{Zn}$ deficiency conditions is unknown.

Metagenome functional predictive analysis was carried out using PICRUSt software [48], OTU abundance was normalized by $16 \mathrm{~S}$ rRNA gene copy number, identified using the Greengenes database, and Kyoto Encyclopedia of Genes and Genomes (KEGG) orthologs prediction was calculated [48]. Considering dietary $\mathrm{Zn}$ depletion was the singular variable in our experiments, 12 of the 265 (4.5\%) KEGG metabolic pathways analyzed were differentially-expressed between the Zn deficient and adequate groups (Figure 6A,B). Non-homologous end-joining was most significantly depleted in Zn deficiency, an expected finding as Zn fingers are found in the catalytic subunit of DNA polymerase [49] and are essential for DNA binding and repair [50]. Further, we observed that even basic cecal microbiome metabolism was perturbed under Zn deficiency; pathways involving lipid metabolism, carbohydrate digestion and absorption, and, most pertinent to this study, mineral absorption were significantly depleted in the $\mathrm{Zn}(-)$ group. Other disruptions in microbial pathways involving the biosynthesis of bile acid and secondary metabolites, and xenobiotic detoxification reflect the fundamental requirement of dietary $\mathrm{Zn}$ in $\mathrm{Zn}$ finger motifs and in copper-zinc superoxide dismutase/glutathione enzymes, respectively.

Finally, we utilized a GC-MS (Gas chromatograph-mass spectrometer) to analyze SCFA concentration in the cecal contents of the $\mathrm{Zn}(-)$ and $\mathrm{Zn}(+)$ birds (Figure 7). SCFAs are produced by 
bacterial fermentation and serve as a primary metabolic substrate for colonocytes [51]. We observed a significant decrease in the concentration of acetate $\left(C_{2}\right)$ and hexanoate $\left(C_{6}\right)$ in $\mathrm{Zn}(-)$ cecal contents. Pertinent to our results, SCFAs may increase dietary $\mathrm{Zn}$ absorption via a decrease in luminal $\mathrm{pH}$ in the intestines [52], thereby increasing Zn solubility, and/or via stimulation of the proliferation of intestinal epithelial cells leading to an increase in the overall absorptive area of the intestines [53]. In this study, a decrease in SCFA concentration in the $\mathrm{Zn}(-)$ group may have followed from either the observed bacterial composition shifts and/or the decreased output of carbohydrate metabolism and fermentation via changes in microbial metabolic pathways. In the host, this may initiate a continuous cycle, which serves to limit Zn uptake even in an already Zn deficient state.

$6 \mathrm{~A}$

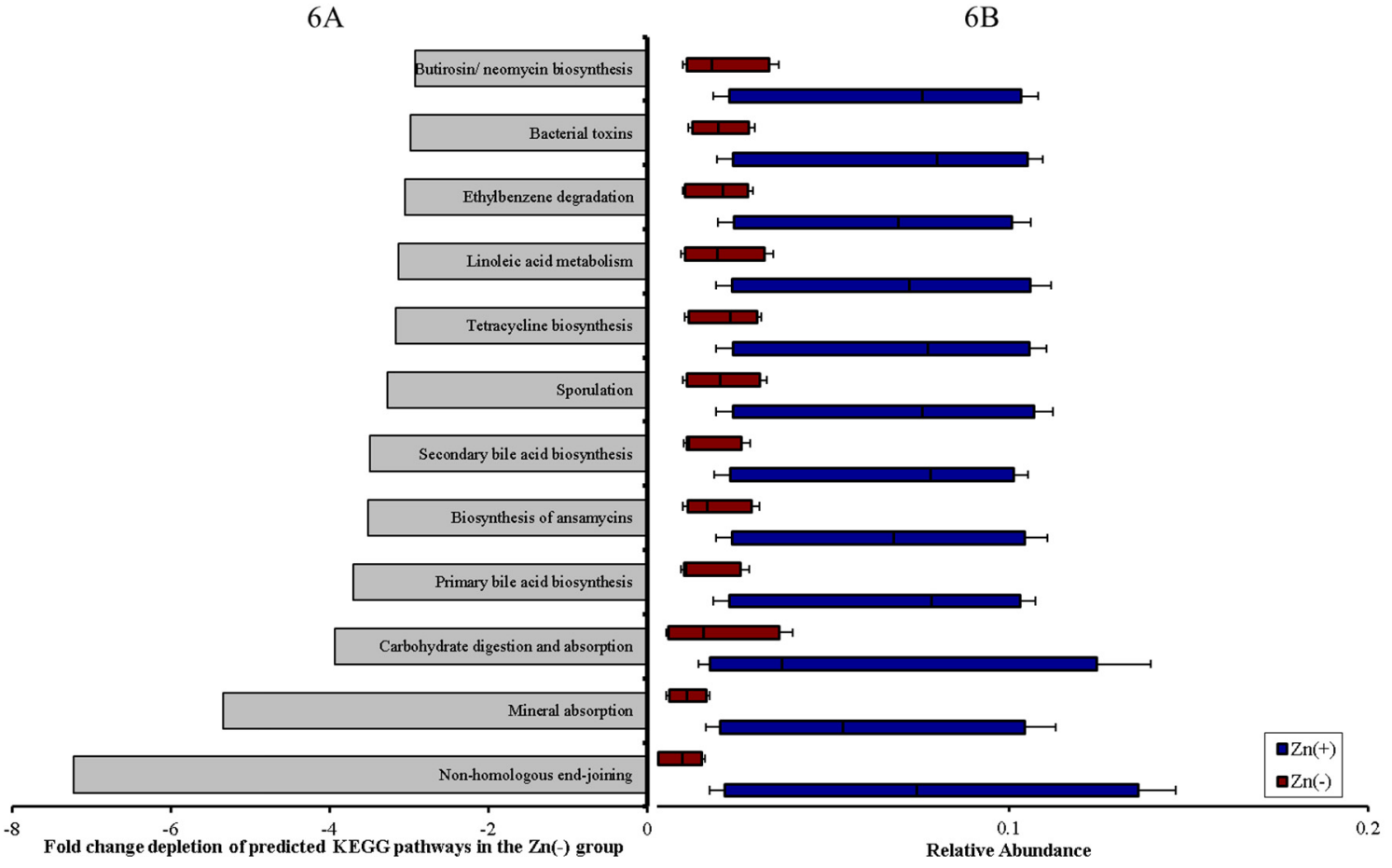

Figure 6. Functional capacity of the cecal microbiota is perturbed under conditions of Zn deficiency. (A) Fold change depletion of these pathways in the $\mathrm{Zn}(-)$ group (all $p<0.01$, Student's $t$-test); (B) Relative abundance of differentially-expressed KEGG microbial metabolic pathways in cecal microbiota. Treatment groups are indicated by the different colors (all $p<0.05$, ANOVA).
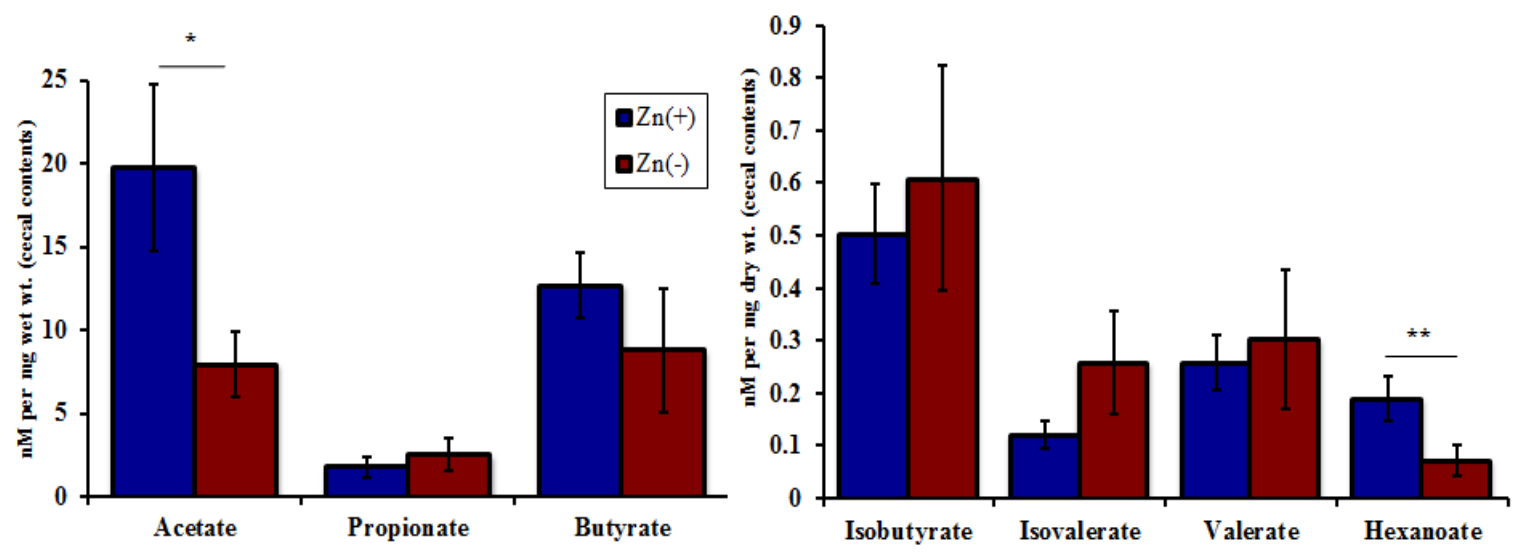

Figure 7. Concentration of short chain fatty acids (SCFAs) in the cecal contents in the $\mathrm{Zn}(+)$ and $\mathrm{Zn}(-)$ groups $\left({ }^{*} p<0.05,{ }^{* *} p<0.01\right.$, ANOVA). 


\section{Discussion}

The gut microbial ecology is known to play a prominent role in host nutritional status, through mechanisms such as modulating saccharide cellular uptake [54], influencing energy balance [46], and de novo biosynthesis of particular vitamins and minerals [55]. The gut, which houses the majority of these microbes, is an important organ in the absorption of $\mathrm{Zn}$ from the diet [56-58]. Insufficient and/or poorly bioavailable dietary $\mathrm{Zn}$ intake are the primary etiological risk factors of Zn deficiency [59-61]. However, to our knowledge, the significance, if any, of compositional and/or functional changes in the gut microbiome during dietary $\mathrm{Zn}$ depletion has yet to be explored.

As is the case in humans and the vast majority of animals, Gallus gallus harbors a complex and dynamic gut microbiota [62], heavily influenced by host genetics, environment, and diet [63]. There is considerable similarity at the phylum level between the gut microbiota of broilers (Gallus gallus) and humans, with Bacteroidetes, Firmicutes, Proteobacteria, and Actinobacteria representing the four dominant bacterial phyla in both $[54,64]$. Due to its rapid maturation and well-characterized phenotype during mineral deficiency, Gallus gallus has been used extensively as a model of human nutrition, especially as it pertains to assessing physiological outcomes of low dietary Fe and Zn [65-72]. Therefore, a central aim of the present study was to use Gallus gallus as a model to characterize cecal bacterial community changes between $\mathrm{Zn}$ deficient and $\mathrm{Zn}$ replete groups. Our data demonstrate that in chronic Zn deficiency, species richness, as measured by the Chao1 index, and species diversity, as measured by the total observed OTUs, were both significantly decreased. Conversely, a significant increase in UniFrac distances was observed in the $\mathrm{Zn}$ deficient group, signifying the looser community relatedness of the cecal microbiomes of $\mathrm{Zn}$ deficient animals compared with their $\mathrm{Zn}$ replete counterparts. Since $\mathrm{Zn}$ is an essential mineral for many bacteria [73], we suggest that a Zn-depleted environment might lead to a less diverse community, preferentially composed of bacterial species that are viable under $\mathrm{Zn}$-limiting conditions. These alterations in cecal microbiota diversity indices mirror those found in a range of GI $[37,38]$ and non-GI disease states [39-42,74]. A similar dysbiotic profile has also been observed in the microbiota of micronutrient-deficient, malnourished children [75,76]. This pattern may exemplify the striking effect of suboptimal dietary $\mathrm{Zn}$ intake, as with other essential micronutrients, on bacterial diversity. Therefore, loss of global diversity of the cecal microbiota during Zn deficiency may be an important, yet non-specific, indicator of suboptimal $\mathrm{Zn}$ intake.

Resident microbes of the gut microbiome compete with their host for various vitamins and transition elements [16,77-79], such as Fe and Zn. Particularly important, Zn ions are involved in numerous structural and catalytic proteins in most organisms, with Zn-binding proteins constituting $10 \%$ of the human proteome and nearly $5 \%$ of the bacterial proteome $[80,81]$. One form of host-microbe competition occurs through the encoding of bacterial transporters, such as the high-affinity $\mathrm{Zn}$ transporter, $\mathrm{ZnuABC}$, in the bacterial genome, representing the essential nature of $\mathrm{Zn}$ for bacterial viability [77]. In our study, the compositional alterations in the Zn deficient group, most notably the significant expansion of the phylum Proteobacteria, as well as the genera Enterobacteriaceae and Enterococcus, may help to explain how dietary $\mathrm{Zn}$ and the microbiota interact, since the ZnuABC transporter has been found to be induced in many species within these bacterial groups under Zn-limiting conditions [82,83]. Lack of sufficient bioavailable dietary Zn in the lumen, therefore, may modulate the gut microbiota by enabling colonization and outgrowth of bacteria that can efficiently compete for $\mathrm{Zn}$. Further, we postulate that microbe-microbe interactions through a decrease in the preponderance of members of the Firmicutes phylum such as the genus Clostridium, known SCFA producers, may explain the overgrowth of these bacteria in the $\mathrm{Zn}(-)$ group [84]. SCFAs have been shown to inhibit the growth of certain Proteobacteria such as members of the Enterobacteriaceae in vivo [84-86], and thus a decrease in SCFA concentration may further explain the cecal compositional shift observed during Zn deficiency. Additionally, alterations in the luminal environment of the intestines, such as a reduction in $\mathrm{pH}$ through increased SCFA production, can result in a notable increase in $\mathrm{Zn}$ bioavailability and uptake $[57,87]$. Therefore, our data suggest that changes in the gut 
microbiota composition of the $\mathrm{Zn}$ deficient group can further deplete $\mathrm{Zn}$ availability in an already $\mathrm{Zn}$ deficient state. Although we expected to observe a conservation of endogenous $\mathrm{Zn}$ through compensatory mechanisms in the $\mathrm{Zn}(-)$ group, upregulation of the expression of brush-border membrane proteins responsible for $\mathrm{Zn}$ uptake (i.e., the $\mathrm{ZnT}$ and $\mathrm{ZIP}$ family transmembrane proteins) were not observed in the $\mathrm{Zn}(-)$ group [12]. Thus, our results suggest that the host-microbe balance may tilt in favor of the resident cecal microbiota (i.e., the sequestration of $\mathrm{Zn}$ by the microbiota) during chronic Zn deficiency.

As opposed to the competition-based mechanism underlying how altered $\mathrm{Zn}$ availability may structurally change the gut microbiota, a compensation-based mechanism may explain the metagenomic differences between the two groups. In the Zn deficient group, depletion of a key KEGG pathway, the mineral absorption pathway, was observed. The interplay between inadequate host $\mathrm{Zn}$ availability and commensal gut microbes may be implicated in the compensation for the relative lack of dietary $\mathrm{Zn}$ in the $\mathrm{Zn}(-)$ group; accordingly, this might lead to a depletion in bacterial pathways responsible for $\mathrm{Zn}$ uptake, and an enrichment in host mineral absorption pathways for the purpose of improving systemic $\mathrm{Zn}$ status. Additionally, lack of $\mathrm{Zn}$ available to the bacteria might also cause a decrease in bacterial $\mathrm{Zn}$ accumulation.

Another aim of our study was to identify correlations between candidate microbes and commonly-used biological indicators of $\mathrm{Zn}$ deficiency (Figure 5C). Clostridium indolis, a microbe we found to be negatively correlated with bodyweight and $\mathrm{Zn}$ adequacy, has been isolated from clinical samples of both animal and human infections [88], and may have the potential to produce beneficial SCFAs such as acetate and butyrate [89]. Enterococcus sp. was positively correlated with final body weight, serum Zn, and Zn adequacy. Members of this genus, specifically Enterococcus faecium, have been shown previously to correlate with increased bodyweight [90] and elevated serum Fe levels [91]. The presence of Clostridium lactatifermentans, a SCFA producer, positively correlated with bodyweight, serum $\mathrm{Zn}$, and $\mathrm{Zn}$ adequacy. It has been isolated previously from Gallus gallus, and associated with an improvement in growth and development (as defined by bodyweight) [92]. Aside from these studies, there are little data linking any of these microbes with a purported influence of host $\mathrm{Zn}$ status or overall physiology. Future research using GF animals may elucidate new roles for these specific microbes in the etiology and/or progression of Zn deficiency.

\section{Conclusions}

We have revealed a dramatic compositional and functional remodeling that occurs in the Gallus gallus gut microbiota under chronic $\mathrm{Zn}$ deficient conditions. Compositional alterations in bacterial abundance, in part due to host-microbe and microbe-microbe interactions, lead to changes in the functional capacity of the microbiota, such as SCFA output, which can influence the absorption and availability of dietary $\mathrm{Zn}$ by the host. Our data suggest that as a consequence of this remodeling, a $\mathrm{Zn}(-)$ microbiota has the potential to perpetuate, and perhaps even aggravate, the Zn deficient condition through the further sequestration of $\mathrm{Zn}$ from the host (Figure 8). Such a microbiota are not functionally compatible with the physiological needs of the $\mathrm{Zn}$ deficient host. In addition, others have observed decreased luminal $\mathrm{Zn}$ solubility in the intestines [87], increased GI inflammation and intestinal permeability, and an overall decline in GI health [93,94] under Zn deficiency. Our findings add to this knowledge by suggesting possible mechanisms by which the gut microbiota may contribute to host $\mathrm{Zn}$ deficiency. Further research should determine whether the gut microbiome could represent a modifiable risk factor for chronic Zn deficiency. 


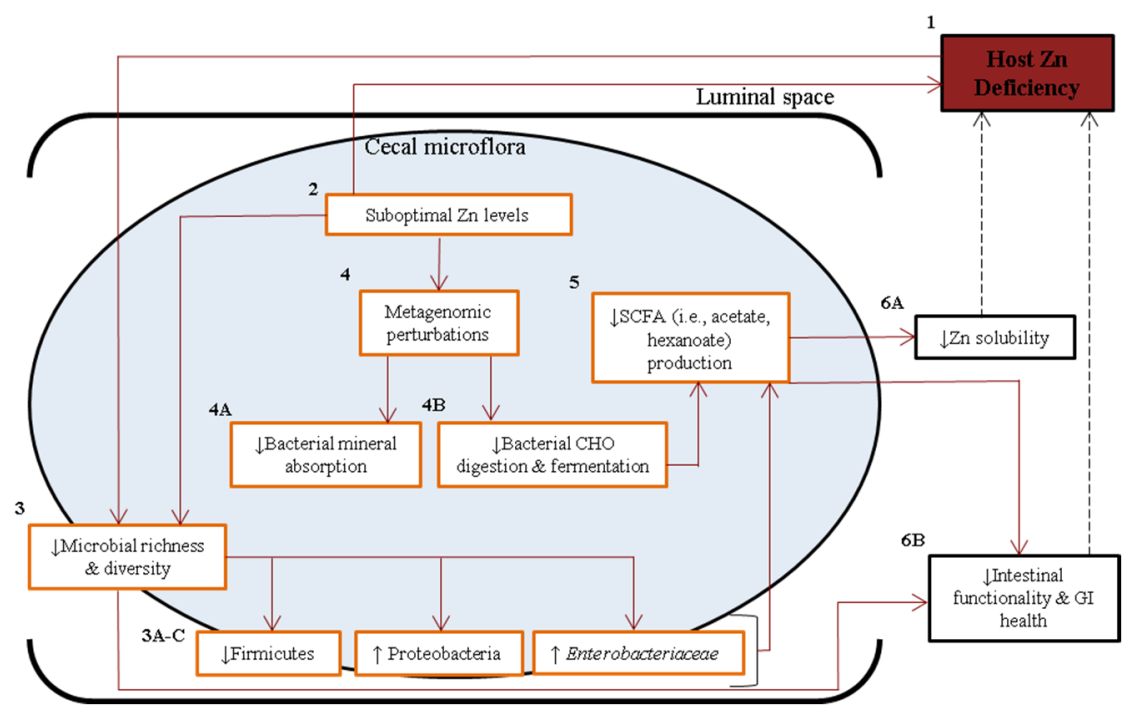

Figure 8. Schematic diagram depicting proposed mechanisms by which a Zn deficient gut microbiome may worsen a Zn deficient phenotype. Zn deficiency (1), caused by insufficient dietary Zn (2), induces a decrease in gut microbial diversity (3), and an outgrowth of bacteria particularly suited to low $\mathrm{Zn}$ conditions, leading to dysbiosis [3A-C]. Lack of dietary $\mathrm{Zn}$ also leads to alterations in the functional capacity of the microflora (4), causing multiple effects including decreased expression of pathways related to mineral (i.e., $\mathrm{Zn}$ ) absorption (4A) and carbohydrate digestion and fermentation (4B). A decrease in the latter pathway may also cause a depression in the production of SCFAs (5), compounds responsible for improving the bioavailability of $\mathrm{Zn}$. Altogether, these microbial effects may decrease $\mathrm{Zn}$ absorbability $(6 \mathrm{~A},[87])$ and disturb GI health $(6 \mathrm{~B},[93,94])$, thereby perpetuating a $\mathrm{Zn}$ deficient state. Red arrows and orange-lined boxes denote observations of this study, and dashed arrows and black-lined boxes describe published findings.

Supplementary Materials: The following are available online at http://www.mdpi.com/2072-6643/7/12/5497/ s1, Table S1: Composition of the experimental diets, Table S2: Measured genes (Gallus gallus) and tissue-specific 18S rRNA from mRNA.

Author Contributions: SR, OK, and ET designed the research protocol; SR, HN, SM, RPG, OK, and ET collected/ analyzed the data; SR and ET wrote the paper and had primary responsibility for final content; ET is the primary investigator that has led the research conducted and presented in this manuscript. All authors read and approved the final manuscript.

Conflicts of Interest: The authors declare no conflict of interest.

\section{References}

1. Gaither, L.A.; Eide, D.J. Eukaryotic zinc transporters and their regulation. BioMetals 2001, 14, $251-270$. [CrossRef] [PubMed]

2. Berg, J.M.; Shi, Y. The galvanization of biology: A growing appreciation for the roles of zinc. Science 1996, 271, 1081-1085. [CrossRef] [PubMed]

3. Solomons, N.W.; Jacob, R.A. Studies on the bioavailability of zinc in humans: Effects of heme and nonheme iron on the absorption of zinc. Am. J. Clin. Nutr. 1981, 34, 475-482. [PubMed]

4. King, J.C.; Cousins, R.J. Zinc. In Modern Nutrition in Health and Disease; Lippincott Williams \& Wilkins Press: Alphen aan den Rijn, The Netherlands, 2006; pp. 271-528.

5. Wintergerst, E.S.; Maggini, S.; Hornig, D.H. Contribution of selected vitamins and trace elements to immune function. Ann. Nutr. Metab. 2007, 51, 301-323. [CrossRef] [PubMed]

6. Rink, L. Zinc and the immune system. Proc. Nutr. Soc. 2000, 59, 541-552. [CrossRef] [PubMed]

7. Wessells, K.R.; Brown, K.H. Estimating the global prevalence of zinc deficiency: Results based on zinc availability in national food supplies and the prevalence of stunting. PLoS ONE 2012, 7, e50568. [CrossRef] [PubMed] 
8. Maret, W.; Sandstead, H.H. Zinc requirements and the risks and benefits of zinc supplementation. J. Trace Elem. Med. Biol. 2006, 20, 3-18. [CrossRef] [PubMed]

9. Sandstead, H.H.; Smith, J.C., Jr. Deliberations and evaluations of approaches, endpoints and paradigms for determining zinc dietary recommendations. J. Nutr. 1996, 126, 2410S-2418S. [PubMed]

10. Gibson, R.S.; Hess, S.Y.; Hotz, C.; Brown, K.H. Indicators of zinc status at the population level: A review of the evidence. Br. J. Nutr. 2008, 99, S14-S23. [CrossRef] [PubMed]

11. Lowe, N.M.; Fekete, K.; Decsi, T. Methods of assessment of zinc status in humans: A systematic review. Am. J. Clin. Nutr. 2009, 89, S2040-S2051. [CrossRef] [PubMed]

12. Reed, S.; Qin, X.; Ran-Ressler, R.; Brenna, J.T.; Glahn, R.P.; Tako, E. Dietary zinc deficiency affects blood linoleic acid: Dihomo-ihlinolenic acid (LA:DGLA) ratio; a sensitive physiological marker of zinc status in vivo (Gallus gallus). Nutrients 2014, 6, 1164-1180. [CrossRef] [PubMed]

13. Guyatt, G.H.; Oxman, A.D.; Ali, M.; Willan, A.; McIlroy, W.; Patterson, C. Laboratory diagnosis of iron-deficiency anemia: An overview. J. Gen. Intern. Med. 1992, 7, 145-153. [CrossRef] [PubMed]

14. Brugnara, C. Iron deficiency and erythropoiesis: New diagnostic approaches. Clin. Chem. 2003, 49, 1573-1578. [CrossRef] [PubMed]

15. Smith, J.C.; McDaniel, E.G.; McBean, L.D.; Doft, F.S.; Halstead, J.A. Effect of microorganisms upon zinc metabolism using germfree and conventional rats. J. Nutr. 1972, 102, 711-719. [PubMed]

16. Gielda, L.M.; DiRita, V.J. Zinc competition among the intestinal microbiota. mBio 2013, 3, e00171-12. [CrossRef] [PubMed]

17. Vahjen, W.; Pieper, R.; Zentek, J. Increased dietary zinc oxide changes the bacterial core and enterobacterial composition in the ileum of piglets. J. Anim. Sci. 2001, 89, 2430-2439. [CrossRef] [PubMed]

18. Pieper, R.; Vahjen, W.; Neumann, K.; VanKessel, A.G.; Zentek, J. Dose-dependent effects of dietary zinc oxide on bacterial communities and metabolic profiles in the ileum of weaned pigs. J. Anim. Physiol. Anim. Nutr. 2012, 96, 825-833. [CrossRef] [PubMed]

19. Vahjen, W.; Pieper, R.; Zentek, J. Bar-Coded Pyrosequencing of $16 S$ rRNA Gene Amplicons Reveals Changes in Ileal Porcine Bacterial Communities Due to High Dietary Zinc Intake. Appl. Environ. Microbiol. 2010, 76, 6689-6691. [CrossRef] [PubMed]

20. Starke, I.C.; Pieper, R.; Neumann, K.; Zentek, J.; Vahjen, W. The impact of high dietary zinc oxide on the development of the intestinal microbiota in weaned piglets. FEMS Microbiol. Ecol. 2014, 87, 416-427. [CrossRef] [PubMed]

21. Hojberg, O.; Canibe, N.; Poulsen, D.; Hedemann, M.S.; Jensen, B.B. Influence of dietary zinc oxide and copper sulfate on the gastrointestinal ecosystem in newly weaned pigs. Appl. Environ. Microbiol. 2005, 71, 2267-2277. [CrossRef] [PubMed]

22. Broom, L.J.; Miller, H.M.; Kerr, K.G.; Knapp, J.S. Effects of zinc oxide and Enterococcus faecium SF68 dietary supplementation on the performance, intestinal microbiota and immune system of weaned piglets. Res. Vet. Sci. 2006, 80, 45-54. [CrossRef] [PubMed]

23. Crane, J.K.; Naeher, T.M.; Shulgina, I.; Zhu, C.; Boedeker, E.C. Effect of zinc in enteropathogenic Escherichia coli infection. Infect. Immun. 2007, 75, 5974-5984. [CrossRef] [PubMed]

24. Sturniolo, G.C.; di Leo, V.; Ferronato, A.; D'Odorico, A.; D'Inca, R. Zinc supplementation tightens leaky gut in Crohn's disease. Inflamm. Bowel Dis. 2001, 7, 94-98. [CrossRef] [PubMed]

25. Salgueiro, M.J.; Zubillaga, M.; Lysionek, A.; Sarabia, M.I.; Caro, R.; de Paoli, T.; Hager, A.; Weill, R.; Boccio, J. Zinc as an essential micronutrient: A review. Nutr. Res. 2000, 20, 737-755. [CrossRef]

26. Bhutta, Z.A.; Darmstadt, G.L.; Hasan, B.S.; Haws, R.A. Community-based interventions for improving perinatal and neonatal health outcomes in developing countries: A review of the evidence. Pediatrics 2005, 115, 519-617. [PubMed]

27. Wood, R.J. Assessment of marginal zinc status in humans. J. Nutr. 2000, 130, S1350-S1354.

28. Hotz, C.; Brown, K.H. Assessment of the Risk of Zinc Deficiency in Populations and Options for Its Control; International Nutrition Foundation: Boston, MA, USA, 2004; pp. S96-S203.

29. Subcommittee on Poultry Nutrition, Committee on Animal Nutrition, Board on Agriculture, National Research Council. Nutrient Requirements of Poultry; National Academies Press: Washington, DC, USA, 1994.

30. Iwaya, H.; Kashiwaya, M.; Shinoki, A.; Lee, J.S.; Hayashi, K.; Hara, H.; Ishizuka, S. Marginal zinc deficiency exacerbates experimental colitis induced by dextran sulfate sodium in rats. J. Nutr. 2011, 141, 1077-1082. [CrossRef] [PubMed] 
31. Haase, H.; Ober-Blobaum, J.L.; Engelhardt, G.; Hebel, S.; Heit, A.; Heine, H.; Rink, L. Zinc signals are essential for lipopolysaccharide-induced signal transduction in monocytes. J. Immunol. 2008, 181, 6491-6502. [CrossRef] [PubMed]

32. Wellinghausen, N.; Rink, L. The significance of zinc for leukocyte biology. J. Leukoc. Biol. 1998, 64, 571-577. [PubMed]

33. Mead, G.C. Bacteria in the gastrointestinal tract of birds. Gastrointest. Microbial. 1997, 2, 216-240.

34. Lan, P.T.; Hayashi, H.; Sakamoto, M.; Benno, Y. Phylogenetic analysis of cecal microbiota in chicken by the use of 16S rDNA clone libraries. Microbiol. Immunol. 2002, 46, 371-382. [CrossRef] [PubMed]

35. Wei, S.; Morrison, M.; Yu, Z. Bacterial census of poultry microbiome. Poult. Sci. 2013, 92, 671-683. [CrossRef] [PubMed]

36. Kasaikina, M.V.; Kravtsova, M.A.; Lee, B.C.; Seravalli, J.; Peterson, D.A.; Walter, J.; Legge, R.; Benson, A.K.; Hatfield, D.L.; Gladyshev, V.N. Dietary selenium affects host selenoproteome expression by influencing the gut microbiota. FASEB J. 2011, 25, 2492-2499. [CrossRef] [PubMed]

37. Manichanh, C.; Rigottier-Gois, L.; Bannaud, E.; Gloux, K.; Pelletier, E.; Frangeul, L.; Nalin, R.; Jarrin, C.; Chardon, P.; Marteau, P.; et al. Reduced diversity of faecal microbiota in Crohn's disease revealed by a metagenomic approach. Gut 2006, 55, 205-211. [CrossRef] [PubMed]

38. Ott, S.J.; Musfeldt, M.; Wenderoth, D.F.; Hampe, J.; Brant, O.; Folsch, U.R.; Timmis, K.N.; Schreiber, S. Reduction in diversity of the colonic mucosa associated bacterial microflora in patients with active inflammatory bowel disease. Gut 2004, 53, 685-693. [CrossRef] [PubMed]

39. Perez-Cobas, A.E.; Artacho, A.; Ott, S.J.; Moya, A.; Gosalbes, M.J.; Latorre, A. Structural and functional changes in the gut microbiota associated to Clostridium difficile infection. Front. Microbiol. 2014. [CrossRef] [PubMed]

40. Giongo, A.; Gano, K.A.; Crabb, D.B.; Mukherjee, N.; Novelo, L.L.; Casella, G.; Drew, J.C.; Ilonen, J.; Knip, M.; Hyöty, H.; et al. Toward defining the autoimmune microbiome for type 1 diabetes. ISME J. 2011, 5, 82-91. [CrossRef] [PubMed]

41. Turnbaugh, P.J.; Hamady, M.; Yatsunenko, T.; Cantarel, B.L.; Duncan, A.; Ley, R.E.; Sogin, M.L.; Jones, W.J.; Roe, B.A.; Affourtit, J.P.; et al. A core gut microbiome in obese and lean twins. Nature 2009, 457, 480-484. [CrossRef] [PubMed]

42. Erb-Downward, J.R.; Thompson, D.L.; Han, M.K.; Freeman, C.M.; McCloskey, L.; Schmidt, L.A.; Young, V.B.; Toews, G.B.; Curtis, J.L.; Sundaram, B.; et al. Analysis of the lung microbiome in the "healthy" smoker and in COPD. PLoS ONE 2011, 6, e16384. [CrossRef] [PubMed]

43. Osendarp, S.; van Raaji, J.M.; Darmstadt, G.L.; Baqui, A.H.; Hautvast, J.G.; Fuchs, G.J. Zinc supplementation during pregnancy and effects on growth and morbidity in low birthweight infants: A randomised placebo controlled trial. Lancet 2001, 357, 1080-1085. [CrossRef]

44. Caulfield, L.; Black, R.E. Zinc deficiency. In Comparative Quantification of Health Risks: Global and Regional Burden of Disease Attributable to Selected Major Risk Factors; Ezzati, M., Lopez, A.D., Rodgers, A., Murray, C.L.J., Eds.; World Health Organization: Geneva, Switzerland, 2004; Volume 1, pp. 257-279.

45. Rossi, L.; Migliaccio, S.; Corsi, A.; Marzia, M.; Bianco, P.; Teti, A.; Gambelli, L.; Cianfarani, S.; Paoletti, F.; Branca, F. Reduced growth and skeletal changes in zinc-deficient growing rats are due to impaired growth plate activity and inanition. J. Nutr. 2001, 131, 1142-1146. [PubMed]

46. Ley, R.E.; Backhed, F.; Turnbaugh, P.; Lozupone, C.A.; Knight, R.D.; Gordon, J.I. Obesity alters gut microbial ecology. Proc. Natl. Acad. Sci. USA 2005, 102, 11070-11075. [CrossRef] [PubMed]

47. Greenblum, S.; Turnbaugh, P.J.; Borenstein, E. Metagenomic systems biology of the human gut microbiome reveals topological shifts associated with obesity and inflammatory bowel disease. Proc. Natl. Acad. Sci. USA 2001, 109, 594-599. [CrossRef] [PubMed]

48. Langille, M.G.; Zaneveld, J.; Caporaso, J.G.; McDonald, D.; Knights, D.; Reyes, J.A.; Clemente, J.C.; Burkepile, D.E.; Vega Thurber, R.L.; Knight, R.; et al. Predictive functional profiling of microbial communities using 16S rRNA marker gene sequences. Nat. Biotechnol. 2013, 31, 814-821. [CrossRef] [PubMed]

49. Sanchez Garcia, J.; Ciufo, L.F.; Yang, X.; Kearsey, S.E.; MacNeill, S.A. The C-terminal zinc finger of the catalytic subunit of DNA polymerase delta is responsible for direct interaction with the B-subunit. Nucleic Acids Res. 2004, 32, 30005-30016. [CrossRef] [PubMed] 
50. Ho, E.; Ames, B.N. Low intracellular zinc induces oxidative DNA damage, disrupts p53, NFkB, and AP1 DNA binding, and affects DNA repair in a rat glioma cell line. Proc. Natl. Acad. Sci. USA 2002, 99, 16770-16775. [CrossRef] [PubMed]

51. Cummings, J.H. Short chain fatty acids in the human colon. Gut 1981, 22, 763-779. [CrossRef] [PubMed]

52. Topping, D.L.; Clifton, P.M. Short-chain fatty acids and human colonic function: Roles of resistant starch and nonstarch polysaccharides. Physiol. Rev. 2001, 81, 1031-1064. [PubMed]

53. Levrat, M.A.; Remesy, C.; Demigne, C. High propionic acid fermentations and mineral accumulation in the cecum of rats adapted to different levels of inulin. J. Nutr. 1991, 121, 1730-1737. [PubMed]

54. Backhed, F.; Ley, R.E.; Sonnenburg, J.L.; Peterson, D.A.; Gordon, J.I. Host-bacterial mutualism in the human intestine. Science 2005, 307, 1915-1920. [CrossRef] [PubMed]

55. Turnbaugh, P.J.; Ley, R.E.; Hamady, M.; Fraser-Liggett, C.M.; Knight, R.; Gordon, J.I. The human microbiome project. Nature 2007, 449, 804-810. [CrossRef] [PubMed]

56. Hara, H.; Konishi, A.; Kasai, T. Contribution of the Cecum and Colon to Zinc Absorption in Rats. J. Nutr. 2000, 130, 83-89. [PubMed]

57. Yonekura, L.; Suzuki, H. Effects of dietary zinc levels, phytic acid and resistant starch on zinc bioavailability in rats. Eur. J. Nutr. 2005, 44, 384-391. [CrossRef] [PubMed]

58. Gopalsamy, G.L.; Alpers, D.H.; Binder, H.J.; Tran, C.D.; Ramakrishna, B.S.; Brown, I.; Manary, M.; Mortimer, E.; Young, G.P. The Relevance of the Colon to Zinc Nutrition. Nutrients 2015, 7, 572-583. [CrossRef] [PubMed]

59. Hambidge, M. Human Zinc Deficiency. J. Nutr. 2000, 130, 1344S-1349S. [PubMed]

60. Shankar, A.H.; Prasad, A.S. Zinc and immune function: The biological basis of altered resistance to infection. Am. J. Clin. Nutr. 1998, 68, 447S-463S. [PubMed]

61. Bhutta, Z.A.; Black, R.E.; Brown, K.H.; Gardner, J.M.; Gore, S.; Hidayat, A.; Khatun, F.; Martorell, R.; Ninh, N.X.; Penny, M.E.; et al. Prevention of diarrhea and pneumonia by zinc supplementation in children in developing countries: Pooled analysis of randomized controlled trials. Zinc Investigators' Collaborative Group. J. Pediatr. 1999, 135, 689-697. [CrossRef]

62. Zhu, X.Y.; Zhong, T.; Pandya, Y.; Joerger, R.D. 16S rRNA-based analysis of the microbiota from the cecum of broiler chickens. Appl. Environ. Microbiol. 2002, 68, 124-137. [CrossRef] [PubMed]

63. Yegani, M.; Korver, D.R. Factors Affecting Intestinal Health in Poultry. Poult. Sci. 2008, 87, $2052-2063$. [CrossRef] [PubMed]

64. Qin, J.; Li, R.; Raes, J.; Arumugam, M.; Burgdorf, K.S.; Manichanh, C.; Nielsen, T.; Pons, N.; Levenez, F.; Yamada, T.; et al. A human gut microbial gene catalogue established by metagenomic sequencing. Nature 2010, 464, 59-65. [CrossRef] [PubMed]

65. Wang, X.B.; Fosmire, G.J.; Gay, C.V.; Leach, R.M. Short-term zinc deficiency inhibits chondrocyte proliferation and induces cell apoptosis in the epiphyseal growth plate of young chickens. J. Nutr. 2002, 132, 665-673. [PubMed]

66. Burrell, A.L.; Dozier, W.A.; Davis, A.J.; Compton, M.M.; Freeman, M.E.; Vendrell, P.F.; Ward, T.L. Responses of broilers to dietary zinc concentrations and sources in relation to environmental implications. Br. Poult. Sci. 2004, 45, 255-263. [CrossRef] [PubMed]

67. Bao, Y.M.; Choct, M.; Iji, P.A.; Bruerton, K. Trace mineral interactions in broiler chicken diets. Br. Poult. Sci. 2010, 51, 109-117. [CrossRef] [PubMed]

68. Cui, H.; Xi, P.; Junliang, D.; Debing, L.; Guang, Y. Pathology of lymphoid organs in chickens fed a diet deficient in zinc. Avian Pathol. 2004, 33, 519-524. [CrossRef] [PubMed]

69. Tako, E.; Rutzke, M.A.; Glahn, R. Using the domestic chicken (Gallus gallus) as an in vivo model for iron bioavailability. Poult. Sci. 2010, 89, 514-521. [CrossRef] [PubMed]

70. Tako, E.; Glahn, R.P. White beans provide more bioavailable iron than red beans: Studies in poultry (Gallus gallus) and an in vitro digestion/Caco-2 model. Int. J. Vitam. Nutr. Res. 2010, 80, 416-429. [CrossRef] [PubMed]

71. Tako, E.; Blair, M.; Glahn, R.P. Biofortified red mottled beans (Phaseolus vulgaris L.) in a maize and bean diet provide more bioavailable iron than standard red mottled beans: Studies in poultry (Gallus gallus) and an in vitro digestion/Caco-2 model. Nutr. J. 2011, 10, 113. [CrossRef] [PubMed] 
72. Tako, E.; Hoekenga, O.; Kochian, L.V.; Glahn, R.P. High bioavailability iron maize (Zea mays L.) developed through molecular breeding provides more absorbable iron in vitro (Caco-2 model) and in vivo (Gallus gallus). Nutr. J. 2013, 12, 3. [CrossRef] [PubMed]

73. Davis, L.M.; Kakuda, T.; DiRita, V.J. A Camplyobacter jejuni znuA Orthologue Is Essential for Growth in Low-Zinc Environments and Chick Colonization. J. Bacteriol. 2009, 191, 1631-1640. [CrossRef] [PubMed]

74. Zhang, X.; Shen, D.; Fang, Z.; Jie, Z.; Qiu, X.; Zhang, C.; Chen, Y.; Ji, L. Human gut microbiota changes reveal the progression of glucose intolerance. PLoS ONE 2013, 8, e71108. [CrossRef] [PubMed]

75. Monira, S.; Nakamura, S.; Gotoh, K.; Izutsu, K.; Watanabe, H.; Alam, N.H.; Endtz, H.P.; Cravioto, A.; Ali, S.I.; Nakaya, T.; et al. Gut Microbiota of Healthy and Malnourished Children in Bangladesh. Front. Microbiol. 2011, 2, 228. [CrossRef] [PubMed]

76. Subramanian, S.; Huq, S.; Yatsunenko, T.; Haque, R.; Mahfuz, M.; Alam, M.A.; Benezra, A.; DeStefano, J.; Meier, M.F.; Muegge, B.D.; et al. Persistent gut microbiota immaturity in malnourished Bangladeshi children. Nature 2014, 510, 417-421. [CrossRef] [PubMed]

77. Hibbing, M.E.; Fuqua, C.; Parsek, M.R.; Peterson, S.B. Bacterial competition: Surviving and thriving in the microbial jungle. Nat. Rev. Microbiol. 2010, 8, 15-25. [CrossRef] [PubMed]

78. Tompkins, G.R.; O'Dell, N.L.; Bryson, I.T.; Pennington, C.B. The effects of dietary ferric iron and iron deprivation on the bacterial composition of the mouse intestine. Curr. Microbiol. 2001, 43, 38-42. [CrossRef] [PubMed]

79. Werner, T.; Wagner, S.J.; Martinez, I.; Walter, J.; Chang, J.S.; Clavel, T.; Kisling, S.; Schuemann, K.; Haller, D. Depletion of luminal iron alters the gut microbiota and prevents Crohn's disease-like ileitis. Gut 2011, 60, 325-333. [CrossRef] [PubMed]

80. Andreini, C.; Banci, L.; Bertini, I.; Rosato, A. Counting the zinc-proteins encoded in the human genome. J. Proteome. Res. 2006, 5, 196-201. [CrossRef] [PubMed]

81. Andreini, C.; Banci, L.; Bertini, I.; Rosato, A. Zinc through the three domains of life. J. Proteome. Res. 2006, 5, 3173-3178. [CrossRef] [PubMed]

82. Yatsunyk, L.A.; Easton, J.A.; Kim, L.R.; Sugarbaker, S.A.; Bennett, B.; Breece, R.M.; Vorontsov, I.I.; Tierney, D.L.; Crowder, M.W.; Rosenzweig, A.C. Structure and metal binding properties of ZnuA, a periplasmic zinc transporter from Escherichia coli. J. Biol. Inorg. Chem. 2008, 13, 271-288. [CrossRef] [PubMed]

83. Abrantes, M.C.; de Fatima Lopes, M.; Kok, J. Impact of Manganese, Copper and Zinc Ions on the Transcriptome of the Nosocomial Pathogen Enterococcus faecalis V583. PLoS ONE 2011, 6, e26519. [CrossRef] [PubMed]

84. Spees, A.M.; Lopez, C.A.; Kingsbury, D.D.; Winter, S.E.; Baumler, A.J. Colonization Resistance: Battle of the Bugs or Ménage à Trois with the Host? PLoS Pathog. 2013, 9, e1003730. [CrossRef] [PubMed]

85. Lawley, T.D.; Walker, A.W. Intestinal colonization resistance. Immunology 2013, 138, 1-11. [CrossRef] [PubMed]

86. Van der Wielen, P.W.; Biesterveld, S.; Notermans, S.; Hofstra, H.; Urlings, B.A.; van Knapen, F. Role of Volatile Fatty Acids in Development of the Cecal Microflora in Broiler Chickens during Growth. Appl. Environ. Microbiol. 2000, 66, 2536-2540. [CrossRef] [PubMed]

87. Coudray, C.; Feillet-Coudray, C.; Gueux, E.; Mazur, A.; Rayssiguier, Y. Dietary Inulin Intake and Age Can Affect Intestinal Absorption of Zinc and Copper in Rats. J. Nutr. 2006, 136, 117-122. [PubMed]

88. Woo, P.C.; Lau, S.K.; Chan, K.M.; Fung, A.M.; Tang, B.S.; Yuen, K.Y. Clostridium bacteraemia characterised by $16 \mathrm{~S}$ ribosomal RNA gene sequencing. J. Clin. Pathol. 2005, 58, 301-307. [CrossRef] [PubMed]

89. Biddle, A.S.; Leschine, S.; Huntemann, M.; Han, J.; Chen, A.; Kyrpides, N.; Markowitz, V.; Palaniappan, K.; Ivanova, N.; Mikhailova, N.; et al. The complete genome sequence of Clostridium indolis DSM 755(T.) Stand. Genomic Sci. 2014, 9, 1089-1104. [CrossRef] [PubMed]

90. Surono, I.S.; Koestomo, F.P.; Novitasari, N.; Zakaria, F.R.; Koesnandar, Y. Novel probiotic Enterococcus faecium IS-27526 supplementation increased total salivary sIgA level and bodyweight of pre-school children: A pilot study. Anaerobe 2011, 17, 496-500. [CrossRef] [PubMed]

91. Capcarova, M.; Weiss, J.; Hrncar, C.; Kolesarova, A.; Pal, G. Effect of Lactobacillus fermentum and Enterococcus faecium strains on internal milieu, antioxidant status and body weight of broiler chickens. J. Anim. Physiol. Anim. Nutr. 2010, 94, e215-e224. [CrossRef] [PubMed] 
92. Torok, V.A.; Hughes, R.J.; Mikkelsen, L.L.; Perez-Maldonado, R.; Balding, K.; MacAlpine, R.; Percy, N.J.; Ophel-Keller, K. Identification and characterization of potential performance-related gut microbiotas in broiler chickens across various feeding trials. Appl. Environ. Microbiol. 2011, 77, 5868-5878. [CrossRef] [PubMed]

93. Wapnir, R.A. Zinc Deficiency, Malnutrition and the Gastrointestinal Tract. J. Nutr. 2000, 130, 1388S-10392S. [PubMed]

94. Rodriguez, P.; Darmon, N.; Chappuis, P.; Candalh, C.; Blaton, M.A.; Bouchaud, C.; Heyman, M. Intestinal paracellular permeability during malnu-trition in guinea pigs: Effect of high dietary zinc. Gut 1996, 39, 416-442. [CrossRef] [PubMed] access article distributed under the terms and conditions of the Creative Commons by Attribution (CC-BY) license (http://creativecommons.org/licenses/by/4.0/). 